\title{
sciendo
}

\section{Shareholder value in Croatian banking sector}

\author{
Ivan Huljak \\ Croatian National Bank, Zagreb, Croatia \\ ivhuljak@gmail.com
}

\begin{abstract}
The view on banks as investments in Croatia is challenged by two phenomena: dual holdings (owners are intensely involved in bank balance sheet as, apart from equity, they provide a significant portion of deposits and loans) and the impediments to determining the cost of equity (as only a handful of banks are traded and with questionable liquidity in the capital market). The paper contributes to the literature by applying the panel regression on the translog cost function in order to calculate the shadow cost of equity for banks in Croatia for the period from 1994 to 2016. In the next step, the Economic Value Added was calculated by taking into account the dual holding role of bank owners. The results suggest that the shareholders economic value is significantly different from the accounting value. In addition, it seems that the standard view that domestic banks are less profitable than foreign banks is only valid from the accounting perspective.
\end{abstract}

Keywords: banking sector, Croatia, panel regression, shareholder value, translog cost function.

JEL classification: C33, G21, L16.

DOI: 10.2478/crebss-2019-0001

Received: November 13, 2019

Accepted: January 15, 2019

Acknowledgments: This work has been partially supported by the Croatian Science Foundation under the project STRENGTHS no. IP-2013-9402.

Disclaimer: The views expressed in the article do not necessarily reflect the views of European Central Bank or Croatian National Bank.

\section{Introduction}

The important role they play in the functioning of the economy justifies large and growing academic interest in the banking sector in Croatia. Additionally, the Croatian banking sector provides a solid test ground for research having been through a period of banking crisis, a credit boom, Global Financial Crisis and stagnation over the last 18 years. Therefore, it is not surprising that the number of academic research on the Croatian banking market functioning increased significantly over the last ten years (Huljak, 2015).

However, discussions about the bank shareholders position in Croatia usually face a couple of constraints. First, the cost of equity estimation for banks in Croatia is 
constrained as only a small number of banks are traded on the stock market and with low liquidity, therefore, impairing Capital Asset Pricing Model (CAPM), or any other market-based method for its calculation. The CAPM requires three components for the cost of equity calculation: a) asset's sensitivity to non-diversifiable risk, b) expected return of the market and c) the expected return of a theoretical risk-free asset. Secondly, foreign-owned banks usually use a significant portion of secondary funds from owners. These funds, although interest paying cannot be considered as pure secondary funds and from a shareholders perspective, they should not be treated as such. Finally, one of the Croatian banks' specificity is relatively high equity ratios. This is a result of banks reaction to macro-prudential measures taken by Croatian National Bank (CNB) in the period of strong credit growth one side and shallow capital market and the need to hold excess buffer on the other.

Significant contribution to better understanding of the bank shareholder position, in general, was provided by the use of Economic Value Added methodology (EVA, knowing that EVA®, is a trademark of Stern Value Management). Initially, Hughes et al. (2003) made a significant contribution to understanding different goals between bank owners and managers. Fiordelisi (2007) continued this line of work and used EVA as an indicator of bank owner's gain as opposed to the gap between ROE and cost of equity. The same author made a step further and calculated the shareholder value efficiency based on Stochastic Frontier Approach and concluded that (over the period 1997-2002 French, German, Italian and UK) banks were on average 36\% shareholder value inefficient. Further, on, Fiordelisi and Molyneux (2010) used the large sample of European banks between 1998 and 2005 and showed that shareholder value has a positive relationship with cost efficiency while economic profits are linked to revenue efficiency. Finally, Radic (2015) applied EVA for a single country (Japan). However, while previous work was based on CAPM methodology the author used a translog cost function to generate shadow price of equity. This study finds that cost efficiency, credit risk and size determine bank shareholder value creation in Japan.

The hypothesis of this research is that bank shareholder value in Croatia is larger when viewed from economic than from accounting stance. This hypothesis is based on the fact that the main driver of bank profitability changes was credit risk or, more precisely, accumulation of loan loss provisions that do not necessarily turn to losses but are treated as such in accounting procedures. Given this, shareholder position for domestic banks should be significantly more favourable from economic than accounting view. Subsequently, the period after the Global Financial Crisis is not necessarily a period of shareholder value depletion.

This paper contributes to the literature on the Croatian banking sector by applying the Economic Value Added concept on banks as suggested by Fioderlisi and Molyneux (2010). However, this concept cannot be directly applied to non-traded banks, since the cost of equity calculation requires substantial market data. Therefore, instead of relying on CAPM, this research follows Radic (2015) concept and apply shadow pricing technique for the cost of equity estimation. Therefore, in the first step, the cost of equity is calculated by utilizing a translog cost function, which does not require market data. This is an important contribution as the cost of equity calculation for banks in Croatia is not available on bank level. Secondly, economic, as opposed to accounting approach to calculating shareholder value gap, is used. Thirdly, a modification of EVA in order to respect the dual holding position of bank owners is proposed, as they are important creditors as well as owners of banks. The analysis is performed by using a unique dataset from 1994 to 2016 , which captures a full loan and NPL cycle. 
The paper is organized as follows: After the introduction, an overview of the Croatian banking sector is provided followed by data and methodology. Chapter four presents empirical results, while chapter five concludes.

\section{Croatian banking sector from shareholders' perspective}

Croatian banking sector went through three different periods from 1994 to 2016 , compare to Table 1. During the early and mid-nineties, the number of banks initially increased due to the lenient licencing policy aimed at increasing the competition via lowering concentration. This resulted in the number of banks reaching 60 in 1998 (Kraft, Hofler, Payne, 2006). However, the banking crisis in the late nineties resulted in one quarter of the banks leaving the market. Parallel with the crisis, the restructuring of the market was taking place as foreign players entered the market usually via the acquisition of an existing bank. After 2002, the banking sector was stable regarding ownership with further consolidation being gradual. However, all until 2008, the period of high credit growth followed during which central banks required (using a set of various measures) equity growth to follow loan growth. In this period of strong credit growth and high earnings, consolidation on the market slowed down.

Finally, after the start of the crisis in 2008, credit growth slowed down and earnings decreased mainly due to high credit risk. With a somewhat improved macroeconomic environment after 2013, the profitability of banks recovered (International Monetary Fund, 2018). However, for a small, stagnating market with characteristically high fixed costs and weak accounting results, the consolidation process seems slow, especially for (from accounting perspective) less profitable domestic banks.

Table 1 Selected accounting indicators for banks in Croatia

\begin{tabular}{|c|c|c|c|c|}
\hline Year & Number of banks & Return on equity (\%) & Equity to assets (\%) & Credit risk (\%) \\
\hline 1994 & 47 & -11.4 & 10.1 & n.a. \\
1996 & 58 & 9.9 & 11.2 & 10.3 \\
1998 & 60 & -12.3 & 10.3 & 9.7 \\
2000 & 51 & 11.6 & 11.9 & 14.9 \\
2002 & 46 & 16.4 & 9.5 & 7.4 \\
2004 & 37 & 19.4 & 8.6 & 5.0 \\
2006 & 33 & 13.7 & 10.3 & 3.2 \\
2008 & 33 & 11.8 & 13.5 & 2.6 \\
2010 & 32 & 7.8 & 14.0 & 4.8 \\
2012 & 30 & 5.6 & 14.3 & 5.9 \\
2014 & 27 & 2.5 & 14.1 & 8.7 \\
2016 & 25 & 9.6 & 14.1 & 9.7 \\
\hline
\end{tabular}

Note: Credit risk is calculated as a ratio of loan loss reserves and gross loans.

Source: Own calculation based on CNB data

Looking at the accounting indicators one could easily conclude that after the crisis Croatian banking sector failed to yield returns even close to the pre-crisis levels. In the same time, the involvement of owners in banks remained high but started to decline with owners providing up to one-third of all funding at some point. In addition, having in mind the specificity of market reshuffle phase from 1994 to 2002, that also did not yield many earnings, it seems that judging from the accounting indicators, only in the period 2002-2008 banks generated substantial value to their shareholders. 


\section{Research methodology}

According to EVA methodology, shareholder value as an absolute value of (Kuna) surplus created by a bank for shareholders in every year was defined. This is done by calculating the difference between "economic measure" of bank net operating profits after taxes (NOPAT) and absolute cost of capital over the same period (cost of equity times capital invested). More precisely, EVA is defined as the follows:

$$
E V A=N O P A T-C A P * C O E,
$$

where EVA is Economic Value Added, NOPAT is net operating profit after tax, CAP is the capital invested and COE is the cost of capital. Alternatively, EVA can be expressed relative to capital investment which yields form one might consider an economic alternative to ROE vs. COE gap:

$$
E V A / C A P=N O P A T / C A P-C O E \text {. }
$$

Given data at disposal and considering bank owners' dual holdings, the EVA calculation is modified as described in Table 2.

Table 2 Adjustments made in order to move accounting values closer to their economic values

\begin{tabular}{|l|l|}
\hline NOPAT & CAPITAL INVESTMENT \\
\hline = Net operating income after tax & = Accounting equity \\
+Interest income for owners & + Loans and deposits from owners \\
+ Loan loss provisions & $\begin{array}{l}\text { Loan loss reserves } \\
\text { - Write-offs }\end{array}$ \\
+Training and R\&D expenses &
\end{tabular}

Note: Research and development, personnel training costs, capitalised costs and differed tax credit is not available from the data sources used. However, judging from euro area banks balance sheets, these items are of less significance. It is assumed that $10 \%$ of administrative costs are training costs and research and development costs, with half of them being capitalised.

Source: Own calculation based on CNB data.

Even after the modification of accounting indicators and controlling for the dual role of shareholders, the EVA calculation still requires the COE calculation. Without the proper market data, the shadow prices approach was used as suggested by Radic (2015). A translog cost function of a bank is defined as follows:

$$
\ln T C_{i t}=\alpha_{0}+\ln T C\left(y_{i t}, w_{i t} ; \beta\right)+\varepsilon_{i t} \text {, }
$$

where $\alpha_{0}$ is a constant, $i$ refers to the cross-sectional unit and $t$ refers to time, $T C_{\text {it }}$ represents total costs, $T C\left(y_{i t}, W_{i t}, \beta\right)$ is a function of outputs and the input prices, $y_{i t}$ are outputs produced by bank $i$ at time $t, w_{\text {it }}$ are input prices, $\beta$ is a vector of parameters. Finally, In denotes the natural logarithm. A translog cost function for $T C\left(y_{i t}, w_{i t}, \beta\right)$ is used with three inputs and two outputs, while including both a linear and a quadratic time trend and the bank capital ratio to capture technological progress and risk considerations, respectively. In the framework, banks produce loans and other earning assets (mostly securities), while utilising labour, physical capital and financial funds. Here the procedure suggested by Altunbas et al. (2007) and Boucinha, Ribeiro and Weyman-Jones (2013) who include two bank outputs and three bank inputs, has been followed.

Assuming a translog cost function for $\operatorname{lnTC}\left(\mathrm{y}_{i t}, \mathrm{w}_{\mathrm{it}}, \beta\right)$, Equation (3) can be written as follows: 


$$
\begin{aligned}
\operatorname{lnTC} C_{i, t}=\alpha_{0}+ & \sum_{h=1}^{2} \alpha_{h} \ln y_{i, t}+\sum_{j=1}^{3} \beta_{j} \ln w_{i, t}+\tau_{1} \ln E_{i, t}+t_{1} T \\
& +\frac{1}{2}\left[\sum_{h=1}^{2} \sum_{j=1}^{3} \delta_{h i} \ln y_{i, t} \ln y_{i, t}+\sum_{h=1}^{3} \sum_{h=1}^{3} \gamma_{i j} \ln w_{i, t} \ln w_{i, t}+\varphi_{1} \ln E_{i, t} \ln E_{i, t}\right. \\
& \left.+t_{11} T^{2}\right]+\sum_{h=1}^{2} \sum_{j=1}^{3} \rho_{i j} \ln y_{i, t} \ln w_{i, t} \\
& +\sum_{h=1}^{2} \omega_{i} \ln y_{i, t} \ln E_{i, t}+\sum_{h=1}^{2} \varphi_{i} T \ln y_{i, t}+\sum_{j=1}^{3} \theta_{j} \ln w_{i, t} \ln E_{i, t} \\
& +\sum_{j=1}^{3} \vartheta_{j} T \ln w_{i, t}+\varepsilon_{i t},
\end{aligned}
$$

where $i$ denotes the bank and $t$ denotes the time period, $\ln T C\left(y_{i t}, w_{i t}, \beta\right)_{i, t}$ is the logarithm of the total cost, $y_{i}(i=1,2)$ is output, $w_{j}(j=1,2,3)$ are prices of inputs, In $E_{t}$ is the logarithm of the capital ratio, and $T$ is a time trend.

To calculate the shadow cost of equity, the first derivative of the cost function, where the equity ratio is one of the fixed inputs, was defined:

$$
\operatorname{SHCOE}_{k}^{*}=-\frac{\partial T C_{i . t}}{\partial E_{i . t}}
$$

where SHCOE is the shadow cost of equity, TC is total cost and $\mathrm{E}$ is equity ratio.

Therefore, the shadow price of equity indicates how much banks saves in total costs when operating with one additional unit of equity ratio, or implicitly how much a bank would be willing to pay for an additional unit of equity.

In order to guarantee the linear homogeneity in factor prices, it was assumed, as follows: $\sum_{j=1}^{3} \beta_{j}=1 ; \sum_{j=1}^{3} \gamma_{i j}=0 ; \sum_{j=1}^{3} \rho_{i j}=0$. To implement linear homogeneity into the translog cost function, it is necessary and sufficient to apply the following standard restrictions on symmetry: $\delta_{i j}=\delta_{j i}$ and $\gamma_{i j}=\gamma_{j i}$. Therefore, to impose linear homogeneity restrictions, the dependent variable and all input prices were normalized by the price of labour $\left(w_{1}\right)$.

\section{Results and discussion}

The shadow cost of equity estimates for 1994 to 2016 indicates a long-term average of $9.4 \%$. For a specific period 2004-2015, for which a comparison with CAPM numbers published by Croatian National Bank is possible, the results are comparable $18.5 \%$ and 9.2\%), Croatian National Bank (2009) however, CAPM results are more volatile.

It is important to notice that while the shadow cost of equity would be comparable with CAPM in the longer horizon and while they both represent implicit cost; their dynamics still differentiates which requires explanation. To understand this, it is vital to emphasize that the shadow price of equity shows the marginal utility of equity in terms of leading to lower total costs. Therefore, the shadow price of equity is marginal savings in an industry given one additional unit of equity. By referring to the whole outstanding portfolio, it is normal that these prices are less sensitive compared with market prices based CAPM. On the other hand, CAPM indicates the required return on contemporaneous investment in the bank. However, apart from time dimension and scope differences, it is important to mention that banks in Croatia on average do not raise funds on the capital market, but rather via direct recapitalisations from owners of internal growth (Figure 1). 


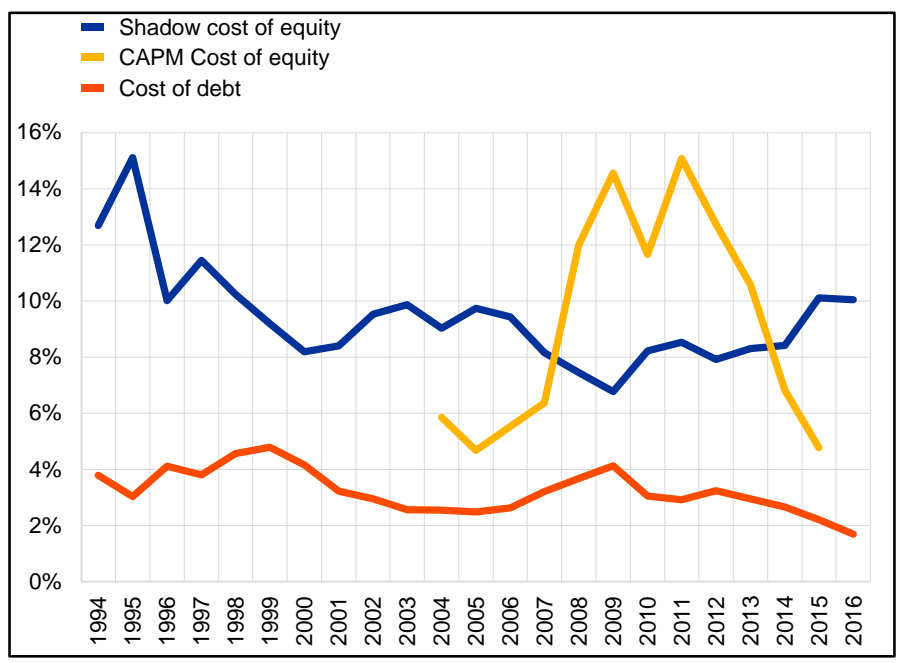

Figure 1 Cost of equity

Source: Own calculation based on CNB data.

Interestingly, no significant differences in the cost of equity between foreign and domestic banks over the whole sample were found. However, this is largely influenced by the first period 1994-2002. Leaving aside the first period (marked with banking crisis); from 2002 onwards foreign banks do have somewhat lower cost of equity as expected (8.7\% vs. 9.4\%). In addition, surprisingly, the cost of equity seems to be higher in precrisis than in crisis period which is contrary to what would CAPM results suggest. To explain this, one has to be aware that strong credit growth in the period 2002-2008 had to be accompanied with equity growth. Therefore, as secondary funding was expensive, having an additional unit of equity paid off, which shadow price of equity clearly reflected.

Regarding standard accounting indicator, ROE, banks experienced only one solid performance period, 2002-2008. The period before was marked with the banking crisis and market restructuring, while the period afterwards was market with the Global Financial Crisis and stagnation. However, opposed to accounting performance of banks, economic performance shows noticeably better results. The ratio of economic return and capital invested suggests that after 2002, banking sector generated around $9 \%$ return on average. This actually has not changed after the start of the crisis. Even more, and perhaps a bit surprisingly, domestic banks seem to generate higher return compared with foreign banks (Table 3).

Table 3 Bank cost of equity and performance

\begin{tabular}{|c|c|c|c|c|c|c|c|c|c|}
\hline \multirow[b]{2}{*}{ Period } & \multicolumn{3}{|c|}{ Cost of equity } & \multicolumn{3}{|c|}{$\begin{array}{l}\text { NOPAT to capital } \\
\text { investment }\end{array}$} & \multicolumn{3}{|c|}{ Return on equity } \\
\hline & $\bar{z}$ & $\begin{array}{l}\frac{5}{0} \\
\frac{0}{0} \\
\frac{0}{4}\end{array}$ & 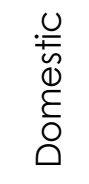 & $\bar{\varangle}$ & $\begin{array}{l}\text {. } \\
\frac{0}{0} \\
\frac{0}{0} \\
4\end{array}$ & 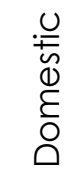 & $\bar{\varepsilon}$ & $\begin{array}{l}\frac{-}{0} \\
\frac{0}{0} \\
\frac{0}{0} \\
\end{array}$ & $\begin{array}{l}\frac{u}{\tilde{U}} \\
\stackrel{\mathbb{U}}{\varepsilon} \\
0 \\
0\end{array}$ \\
\hline 1994-2001 & 10.7 & 11.0 & 10.7 & 15.8 & 14.5 & 16.9 & 3.4 & 13.5 & -1.4 \\
\hline 2002-2008 & 9.0 & 8.9 & 10.6 & 8.9 & 8.8 & 10.2 & 11.5 & 12.0 & 8.1 \\
\hline 2009-2016 & 8.5 & 8.6 & 8.4 & 9.3 & 9.1 & 11.9 & 3.9 & 4.5 & -1.6 \\
\hline
\end{tabular}

Source: Own calculation based on CNB data. 
To better understand the drivers of the economic and accounting performance, two components have to be observed: capital investment and credit risk. It seems that foreign banks require more investment from owners as one-quarter of assets is financed by equity and secondary funds from owners. This is more than twice compared with domestic banks. However, on the other hand, domestic banks have higher credit risk as in all the periods observed their loan loss provisions to total assets is higher. Finally, contrary to the gap in standard accounting shareholder value, it seems that from the economic perspective, domestic banks provide more economic value added for shareholders.

Table 4 Bank selected features and shareholder value gap

\begin{tabular}{|c|c|c|c|c|c|c|c|c|c|c|c|c|}
\hline \multirow[b]{2}{*}{ Period } & \multicolumn{3}{|c|}{$\begin{array}{l}\text { Capital and } \\
\text { secondary funds } \\
\text { to assets }\end{array}$} & \multicolumn{3}{|c|}{$\begin{array}{c}\text { Loan loss } \\
\text { provisions to total } \\
\text { assets }\end{array}$} & \multicolumn{3}{|c|}{$\begin{array}{c}\text { Economic } \\
\text { shareholder value } \\
\text { gap }\end{array}$} & \multicolumn{3}{|c|}{$\begin{array}{c}\text { Accounting } \\
\text { shareholder value } \\
\text { gap }\end{array}$} \\
\hline & $\overline{\bar{\alpha}}$ & $\begin{array}{l}\frac{-}{0} \\
\frac{0}{0} \\
\frac{0}{4} \\
\end{array}$ & 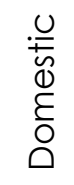 & $\overline{\bar{\alpha}}$ & $\begin{array}{l}\frac{5}{0} \\
\frac{0}{10} \\
\frac{0}{4}\end{array}$ & 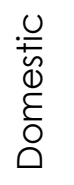 & $\overline{\bar{\psi}}$ & .0 & 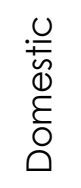 & $\overline{\bar{\psi}}$ & $\frac{c}{\frac{0}{0}}$ & 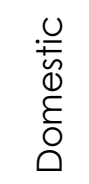 \\
\hline & .3 & $J_{2}$ & & & & 2. & & & & -7. & & -12.1 \\
\hline 2002 & 19.3 & 20.1 & 13.4 & 0.2 & 0.2 & 0.4 & -0.1 & -0.1 & -0.4 & 2.5 & 3.1 & -2.5 \\
\hline 2009-2016 & 26.2 & 28.0 & 11.7 & 1.3 & 1.2 & 1.5 & 0.8 & 0.6 & 3.5 & -4.7 & -4.1 & -10.0 \\
\hline
\end{tabular}

Source: Own calculation based on CNB data.

Therefore, it seems that less invested capital in the domestic banks more than compensated higher credit risk these institutions face. In addition, the accounting gap would consider after the crisis period as worst for owners in general as the loan loss provisions depleted the majority of operating income. However, from the economic perspective, 2002-2008 the period was the worst as the banks required a large investment from owners (Table 4).

\section{Conclusion}

Economic Value Added approach provides a different perspective on bank shareholder value in Croatia. To implement this approach, two adjustments were needed: shadow pricing technique to derive the cost of equity and adjustment for dual holdings of owners (equity and secondary funds). Here presented analysis shows that from the economic perspective, shareholder value is significantly different compared with a more standard ROE vs. COE gap. The standard technique relies on accounting data and is mostly influenced by credit risk. However, from the economic approach perspective, additional value adjustments are additional investments in the company and have a treatment similar to depreciation or training expenses while write-offs are considered as losses.

As expected, contrary to accounting approach, economic approach suggests that even with the banking crisis and Global Financial Crisis effects accounted for, the banking sector in Croatia generated value for its' shareholders amounting to $2.3 \%$ on average for period 1994-2016 confirming the research hypothesis. Also, this value is actually higher for owners of domestic banks which is contrary to general perception. Finally, it appears that from the economic perspective, the period after the Global Financial Crisis and stagnation that followed was not the worst period for bank shareholders as they decreased their investment in the banks. It was actually, the period of aggressive investment in the period 2002-2008 that significantly depleted the 
value for bank shareholders even though in this period banks recorder strong accounting results. Therefore, the initial hypothesis is confirmed completely.

Finally, moving forward, these results could provide solid ground for future research on bank shareholder efficiency (a la Fioderlisi 2007) to provide answers on which banks managed to generate most shareholder value given its everyday and strategic constraints. The limitation of this research refers mostly to unavailability of more granular data on bank revenues and costs therefore somewhat impairing the EVA calculation. More precisely, focusing on individual banks' instead on bank groups could provide an opportunity to further investigate the determinants of shareholder value and investigate the motivation for bank market consolidation in Croatia and why the process sometimes seems slow, especially for domestic banks that are often perceived (from an accounting perspective) as weak investments.

\section{References}

1. Altunbas, Y., Carbo, S., Gardener, E. P. M., Molyneux, P. (2007). Examining the Relationships between Capital, Risk and Efficiency in European Banking. European Financial Management, Vol. 13, No. 1, pp. 49-70.

2. Boucinha, M., Ribeiro, N., Weyman-Jones, T. (2013). An assessment of Portuguese banks' efficiency and productivity towards euro area participation. Journal of Productivity Analysis, Vol. 39, No. 2, pp. 177-190.

3. Croatian National Bank (2009). Box 4 Cost of bank capital. Financial Stability, No. 16, pp. 46-48.

4. Fioderlisi, F. (2007). Shareholder value efficiency in European banking. Journal of Banking \& Finance, Vol. 31, No. 7, pp. 2151-2171.

5. Fiordelisi F., Molyneux P. (2010). The determinants of shareholder value in European banking. Journal of Banking \& Finance, Vol. 34, No. 6, pp. 1189-1200.

6. Huljak, I. (2015). Cost efficiency of banks in Croatia. Croatian Review of Economic, Business and Social Statistics, Vol. 1, No. 1-2, pp. 12-26.

7. Hughes, J. P., Lang W., Mester L., Moone C., Pagano M. (2003). Do bankers sacrifice value to build empires? Managerial incentives, industry consolidation, and financial performance. Journal of Banking \& Finance, Vol. 27, No. 3, pp. 417-447.

8. International Monetary Fund (2018). Republic of Croatia: 2017 Article IV Consultation. Press Release, Staff Report; and Statement by the Executive Director for the Republic of Croatia. IMF Country Report, No. 18/5, pp. 1-75.

9. Kraft, E., Hofler, R., Payne, J. (2006). Privatization, foreign bank entry and bank efficiency in Croatia: a Fourier-flexible function stochastic cost frontier analysis. Applied Economics, Vol. 38, No. 17, pp. 2075-2088.

10. Radic, N. (2015). Shareholder value creation in Japanese banking. Journal of Banking \& Finance, Vol. 52, pp. 199-207.

\section{About the author}

Ivan Huljak, PhD, received a bachelor's degree in finance in 2004 and a Master of Science degree in corporate finance from the Faculty of Economics and Business of the University of Zagreb in 2010. In 2014, he received his PhD in the field of banking and industrial organisation with the thesis "The net effect of bank market power in CEE countries" defended at the Faculty of Economics of the University of Split. In 2016 he acquired the title of a research associate at the Faculty of Economics of the University of Split. He attended numerous seminars, workshops and conferences in Croatia and abroad. From 2004 to 2016, the author worked in the Croatian National Bank, in the Financial Stability Department as an economist, advisor and senior advisor. Since 2016 onwards, the author has been working in European Central Bank, Directorate General Macroprudential Policy and Financial Stability. His main research interests include banking, financial stability and industrial organisation. The author can be contacted ativhuljak@gmail.com. 